\title{
ВИКОРИСТАННЯ ПЕЛЮСТКОВИХ ДІАГРАМ ДЛЯ ВІЗУАЛІЗАЦІЇ РЕЗУЛЬТАТІВ ЕКСПЕРТНОГО ОЦІНЮВАННЯ ЯКОСТІ ПРОГРАМНОГО ЗАБЕЗПЕЧЕННЯ
}

Розроблено методику візуалізації інформації, яку отримують внаслідок оброблення експертних оцінок якості програмного забезпечення (ПЗ) за різними критеріями його оцінювання з використанням пелюсткових діаграм. Встановлено, що під візуалізацією результатів експертного оцінювання якості ПЗ розуміють подання інформації у графічному вигляді для максимальної зручності їі розуміння та швидкого сприйняття, а також надання оглядової та зрозумілої форми будь-якому об'єкту, процесу чи явищу. Запропоновано критерії оцінювання якості ПЗ та їхні вагові коефіцієнти для кожного з експертів, які забезпечують достовірне подання наявного стану процесу розроблення ПЗ, правильне розуміння суті проблем, що можуть виникнути на будь-якому етапі реалізації програмного проекту, і точні характеристики їх складових. Розроблено алгоритм розрахунку площ секторних пелюстків у полярній системі координат, за допомогою яких можна обчислити і оцінити відносну якість ПЗ за відповідними критеріями. Визначено підсумкові комплексні показники якості ПЗ для кожного 3 експертів і узагальнений комплексний показник його якості. Розроблено алгоритм розрахунку площі пелюсткової діаграми у полярній системі координат, який дає змогу визначити ту частину якості ПЗ за всіма критеріями, яку маємо на даний момент за оцінками одного з експертів, а також ту частку якості ПЗ, яку ще потрібно досягти для стовідсоткової її повноти. Зроблено відповідні висновки та надано рекомендації щодо використання розробленої методики візуалізації інформації.

Ключові слова: інформаційні технології; програмний проект; візуалізація інформації; експертні оцінки; якість програмного забезпечення; показники якості програмного забезпечення; критерії оцінювання якості програмного забезпечення; полярна система координат; полярні діаграми.

Вступ. У галузі інформаційних технологій якість програмного забезпечення (ПЗ) є основною характеристикою його ефективного використання (Pleskach, Zatonatska, 2011), позаяк вказує на ступінь його відповідності встановленим вимогам (ISO 9001, 2008; Pomorova, \& Hovorushchenko, 2013). Зазвичай, під якістю ПЗ розуміють набір властивостей програмного продукту, що характеризують його здатність задовольнити встановлені або передбачувані потреби замовника, які він вказав у вигляді користувацьких вимог до ПЗ на початкових етапах його розроблення (Pomorova, \& Hovorushchenko, 2013a, 2013b).

Якість ПЗ оцінюють 3 використанням моделі якості (ISO/IEC 9126-1, 2001). Тут під оцінюванням якості П3 розуміють дії, що визначають, як саме воно відповідає своєму призначенню. Таке оцінювання набуває особливого значення із розвитком і вдосконаленням технологій оброблення експертних даних (Kuliamin, Petrenko, 2008; Morhun, 2011). Усе це призвело до потреби розроблення методів і засобів комплексного оцінювання різноманітних характеристик якості ПЗ, які б враховували деякі невизначеності вхідної інформації та суб'єктивність оцінок експертів (Botsula \& Morhun, 2008; Voronin, Ziatdinov \& Kulinskii, 2011).
На сьогодні експертні технології - невід'ємна складова процесу прийняття управлінських рішень (DeMarco Tom, 2002) як при розробленні ПЗ, при управлінні змінами вимог до нього та ризиками його реалізації, так i під час управління його якістю (Botsula \& Morhun, 2014; Paulk \& Curtis, 2001). Прийняття рішень професійними експертами грунтується практично на достовірному поданні наявної ситуації, правильному розумінні суті проблеми і повноті характеристик їі складових. Кожний експерт, який бере участь в процесі оцінювання якості ПЗ і від думки якого залежить остаточне рішення керівника проекту, повинен володіти необхідними знаннями у своїй предметній області, має мати певний досвід і навики роботи. За їх відсутності такі експерти до участі в оцінюванні якості ПЗ не допускають. Низька їх кваліфікація може призвести до того, що надані експертами оцінки сприятимуть невиправним помилкам і значним втратам - фінансовим, матеріальним i часовим.

Керівник проекту може значно знизити ризики прийняття помилкових рішень за умови використання інформаційних технологій оброблення даних, візуалізації отриманих результатів у вигляді, зручному для швидкого сприйняття та ефективного аналізу, а також

\section{Інформація про авторів:}

Грицюк Юрій Іванович, д-р техн. наук, професор, кафедра програмного забезпечення. Email: yurii.i.hrytsiuk@Ipnu.ua; https://orcid.org/0000-0001-8183-3466; ResearcherID: V-3995-2017

Далявський Владистав Сергійович, студент, кафедра програмного забезпечення. Email: mobivlad@outlook.com

Цитування за ДСТУ: Грицюк Ю. І., Далявський В. С. Використання пелюсткових діаграм для візуалізації результатів експертного оцінювання якості програмного забезпечення. Науковий вісник НлтУ України. Серія Економічна. 2018, т. 28, № 9. С. 95-104.

Citation APA: Hrytsiuk, Yu. I., \& Dalyavskyy, V. S. (2018). Using Petal Diagram for Visualizing the Results of Expert Evaluation of Software Quality. Scientific Bulletin of UNFU, 28(9), 95-104. https://doi.org/10.15421/40280919 
шляхом прогнозування подальших подій, в т.ч. й негативних наслідків від них. Наявні можливості сучасних систем автоматизованого оброблення даних дають змогу керівнику проекту формалізувати якісні та кількісні оцінки від експертів і комплексно оцінити якість ПЗ за різними його характеристиками.

Відомо (Bederson \& Shneiderman, 2003; Card, Mackinlay \& Shneiderman, 1999; Spence, 2007), що термін "візуалізація" походить від латинського visualis сприйняття візуально, унаочнення, створення умов для візуального спостереження. Одне із тлумачень цього терміну вказує на те, що візуалізація - це детальне відтворення в уяві аналітика деякого його бажання. Загалом, візуалізація - це побудова графічного образу даних, що допомагає аналітику під час загального їхнього аналізу вбачати їх аномалії, структури, зв'язки тощо (Kerren et al., 2008). У комп'ютерній графіці візуалізацією (рендерінгом) називають процес отримання зображення за його комп'ютерною моделлю (Mazza, 2009).

Під візуалізацією результатів експертного оиінювання якості ПЗ розумітимемо подання інформації у графічному вигляді для максимальної зручності іiі розуміння та швидкого сприйняття, а також надання осяжної та зрозумілої форми будь-якому об'єкту, процесу чи явищу. Проте, серед значної кількості теоретиків і практиків у галузі інформаційних технологій побутує думка, що таке розуміння візуалізації інформації сприяє мінімальній розумовій і пізнавальній активності аналітика, а візуальні інструментальні засоби виконують для нього тільки ілюстративну функцію (Spence, 2007; Wa$\mathrm{re}, 2000)$. Спробуємо дещо спростувати такі, як на наш погляд, хибні думки і довести неабияку користь візуалізації інформації в галузі розроблення ПЗ та оцінювання його якості.

Аналіз останніх досліджень та публікацій. Експертні методи оцінювання якості продукції добре себе показали в різних виробничих сферах (Botsula \& Morhun, 2008; Pleskach, Zatonatska, 2011). Тому багато теоретиків і практиків у галузі інформаційних технологій спробували перенести цей досвід на процес розроблення ПЗ та управління його якістю (Botsula \& Morhun, 2014; Pomorova \& Hovorushchenko, 2013a). Загалом, застосування експертних технологій дає змогу аналітикам визначити якість як майбутнього та вже розробленого П3, так і складність реалізації програмного проекту (DeMarco Tom, 2002). Також такі технології забезпечують достовірне оцінювання обсягу, тривалості та вартості виконуваних робіт, наукове обгрунтування особливостей виконання завдань проекту й зусилля, витрачені керівником проекту для підготовки, прийняття та реалізації того чи іншого рішення. Однак, експертні оцінки на різних етапах реалізації програмного проекту можуть слугувати тільки підставою для визначення складності його реалізації чи поведінки показників якості ПЗ, а тому мають рекомендаційний характер. Тільки оцінювання експертами готового програмного продукту в реальних умовах його експлуатації може дати достовірну та остаточну оцінку якості П3 (Hrytsiuk \& Buchkovska, 2017a; 2017b).

Особливості застосування моделей оцінювання якості ПЗ за визнаними методиками розглянуто в роботах (Botsula \& Morhun, 2008; ISO/IEC 9126-1, 2001; Nazemi, 2014). Проблема застосування методів і засобів експертного оцінювання якості ПЗ широко висвітлена в дослідженні (Pleskach, Zatonatska, 2011). У різних наукових працях процес експертного оцінювання якості ПЗ описано з урахуванням компетентності експертів і за умови фіксації вагомостей кожного з них за встановленими критеріями (Morhun, 2011). Водночас, у роботі (Botsula \& Morhun, 2011) запропоновано метод оцінювання якості веб-матеріалів на базі оцінок двох груп респондентів - "користувачі" та "експерти". Автори цієї роботи вважають, що цей метод надає можливість якісно та кількісно подати множини значень оцінок за допомогою діаграми-багатокутника, побудованого у полярній системі координат. Також ними розроблено відповідний програмний засіб для аналізу отриманих оцінок і розрахунку комплексного показника якості вебматеріалів.

Проте, процедура оцінювання якості ПЗ та наявні методи і засоби забезпечення цієї якості, як власне i процес розроблення самого ПЗ ще й на сьогодні залишаються незабезпеченими фундаментальною теорією та ефективною методологією. Більшість досліджень 3 оцінювання якості ПЗ, особливо на ранніх етапах реалізації програмного проекту мають хаотичний, несистематизований характер. Водночас, як доведено у роботах (Pomorova \& Hovorushchenko, 2013a, 2013b), саме в кінці етапу проектування архітектури ПЗ можна й варто виявляти та усувати до 55 \% всіх недоліків майбутнього програмного продукту. Безумовно, є багато фундаментальних досліджень 3 інженерії П3 (роботи Боема, Дейкстри, Мейєра), але відсутня завершена, протестована та апробована теорія та методологія розроблення складного i, водночас, якісного ПЗ, а також методи і засоби оцінювання та прогнозування його якості на ранніх етапах реалізації програмного проекту. Тому теорія та практика оцінювання якості програмних продуктів потребує значних змін для запобігання непередбачених втрат як замовників ПЗ, так і його розробників, а також неприємних інцидентів під час його експлуатації, викликаних помилками роботи.

Не претендуючи на кардинальні зрушення в експертних технологіях, спробуємо внести і свою лепту в експертні методи оцінювання якості ПЗ, особливо у візуалізацію експертної інформації. Тому, як на сьогодні, видається нам актуальним дослідження, яке стосується розроблення адекватної методики візуального подання оцінок експертів у вигляді полярних діаграм, обгрунтування критеріїв оцінювання якості ПЗ та їхньої важливості для кожного з експертів, а також унаочнення комплексних показників якості ПЗ для кожного з експертів зокрема і для усіх експертів загалом.

Об'єкт дослідження - візуалізація результатів експертного оцінювання якості ПЗ.

Предмет дослідження - методи та засоби візуалізації інформації, отриманої внаслідок оброблення експертних оцінок якості ПЗ за різними критеріями, у вигляді, зручному для швидкого сприйняття та ефективного аналізу.

Мета дослідження полягає в розробленні методики візуалізації інформації, отриманої внаслідок оброблення експертних оцінок якості ПЗ за різними критеріями 3 використанням пелюсткових діаграм.

Для реалізації зазначеної мети потрібно виконати такі основні завдання:

1) обгрунтувати подання оцінок експертів у вигляді пелюсткових діаграм, які дадуть змогу лаконічно навести в зображенні те, що в текстовому еквіваленті займе декілька абзаців; 
2) запропонувати критерії оцінювання якості ПЗ та їхні вагові коефіцієнти для кожного з експертів, які забезпечать достовірне подання наявної ситуації, правильне розуміння суті проблеми і певні характеристики іiі складових;

3) визначити підсумкові комплексні показники якості ПЗ для кожного 3 експертів зокрема і для узагальненого експерта загалом, які дадуть змогу аналітикам обчислити і оцінити відносну якість розроблюваного ПЗ;

4) зробити відповідні висновки та надати рекомендації щодо використання розробленої методики візуалізації інформації.

Подання оцінок експертів у вигляді полярної діаграми. Результати багатьох досліджень (Bederson, \& Shneiderman, 2003; Card, Mackinlay, \& Shneiderman, 1999; Heer, Card, \& Landay, 2005) показують, що продуктивність праці аналітика, який використовує візуальну інформацію, зростає до $17 \%$. Багато науковців (Spence, 2007; Ware, 2000) вважають, що завдяки унаочненню інформації людина може запам'ятати такі ії деталі, які в тексті не привернули б увагу навіть прискіпливого читача, який вдумується в прочитане та аналізує його. Якщо ж інформація (наприклад, бізнес-вимоги до ПЗ) надходить від замовника ПЗ до аналітика не просто у вигляді набору тексту, а $з$ відповідними рисунками, схемами та іншими візуальними об'єктами, то таку інформацію, безсумнівно, аналітик сприймає набагато швидше та значно легше i, як наслідок, врази більше.

За останні роки в галузі інформаційних технологій відбулися колосальні зміни - зріс не тільки обсяг нової інформації, а й помінялась іiі якість: попри якісну нову інформацію появилось так зване інформаційне сміття. З'явилися також нові види візуальної інформації та форми іiі подання. 3 огляду на цю ситуацію, під візуалізаизією інформації (англ. Information Visualisation) розуміють інтерактивне вивчення графічного подання абстрактних даних для посилення людського пізнання (Mazza, 2009). Абстрактні дані можуть містити як числову й текстову інформацію, так і графічне їі подання. Водночас, візуалізачія даних (англ. Data Visualisation) це графічна презентація інформації, завдяки якій можна

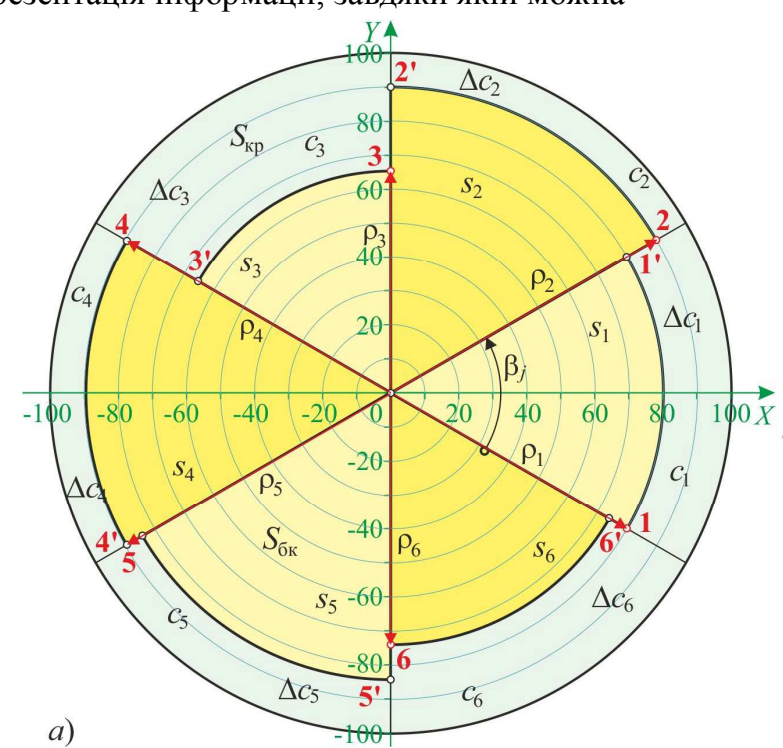

a)

Рис. 1. Подання критеріїв оцінювання якості ПЗ у полярній системі координат

Автори у роботі (Botsula \& Morhun, 2011) стверджують, що кут $\beta$ між векторами утворює сектор, величина якого характеризує вплив відповідного критерію на за- лаконічно подати в зображенні те, що в текстовому еквіваленті займе декілька абзаців.

У цьому дослідженні, як і в попередніх роботах (Hrytsiuk \& Buchkovska, 2017a; 2017b) спробуємо розробити методику візуалізації результатів експертного оцінювання якості ПЗ за різними критеріями, де врахуємо як різну важливість кожного з критеріїв, так і вагомість самих експертів, що дасть змогу комплексно оцінити якість ПЗ -наявного та майбутнього.

Для візуалізації результатів опитувань експертів за деякими критеріями оцінювання якості ПЗ (Botsula \& Morhun, 2011) та отримання його комплексного показника спробуємо використати полярні діаграми. Зазвичай, під полярною діаграмою розуміють графічний спосіб відображення абстрактних даних у вигляді круга, поділеного на три і більше секторів відповідними векторами (змінними). Ці змінні відображають на осях полярної системи координат, що мають спільний початок. Початок відліку та кут нахилу векторів, зазвичай, у полярній діаграмі вказують, що є корисним як для кількісного, так і якісного відображення інформації. У різній науковій літературі (Kerren et al., 2008; Mazza, 2009; Spence, 2007) можна натрапити на такі назви полярної діаграми: веб-діаграма, павукоподібна діаграма, карта зоряного неба, зоряна діаграма, неправильний багатокутник і пелюсткова діаграма.

Критерії оцінювання якості ПЗ подамо у вигляді векторів (змінних) в полярній системі координат, які ділять круг на сектори, що загалом утворюють полярну діаграму (рис. 1,a). Кожний вектор має такі показники, як довжину і кут нахилу до попереднього вектора. Вважатимемо, що довжина вектора відповідає кількісному показнику якості ПЗ за відповідним критерієм. Як виняток, максимальна довжина будь-якого 3 векторів має відповідати стовідсотковій якості ПЗ за відповідним критерієм. Зазвичай, реальна довжина кожного 3 векторів становить тільки певну частину від його максимальної довжини, що відповідає реальній якості ПЗ за відповідним критерієм.

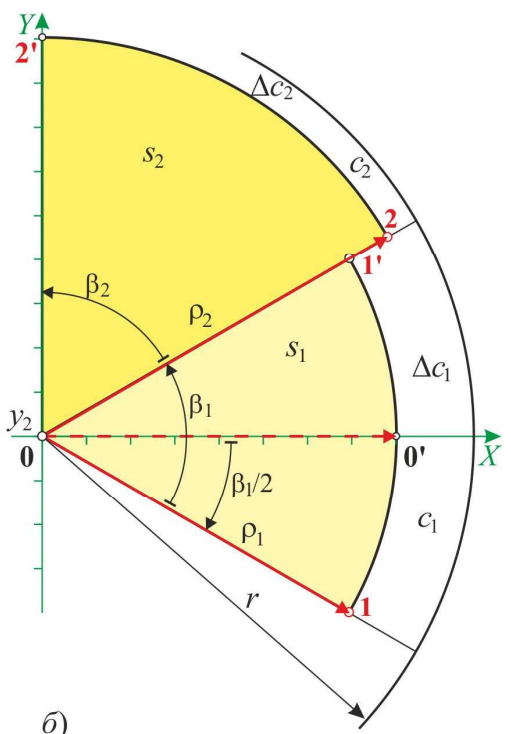

гальний результат оцінювання якості ПЗ. Якщо всі критерії мають однаковий вплив на якість ПЗ, то вектори відповідних критеріїв будуть рівномірно розподілені по кругу полярної системи координат. Наприклад, для 
шести критеріїв цей кут між усіма векторами становитиме $\beta=2 \pi / 6$. У випадку неоднакового впливу критеріїв на якість ПЗ, то кути між відповідними векторами визначають за формулою

$$
\tilde{\mathrm{B}}=\left\{\beta_{j}=2 \pi \cdot w_{j} / \sum_{i=1}^{N} w_{i}, j=\overline{1, N}\right\},
$$

де: $\tilde{W}=\left\{w_{j}, j=\overline{1, N}\right\}-$ ваговий коефіцієнт $j$-го критерію оцінювання якості ПЗ; $N$ - кількість критеріїв оцінювання якості ПЗ.

Якщо відкласти вектори-критерії $\left(\rho_{1}, \ldots, \rho_{6}\right)$ у полярній системі координат і через кожну точку їхніх вершин у кожному секторі провести дугу радіусом $\rho_{j}$, то матимемо так звану пелюсткову діаграму 1-1',2-2',...,6-6' (рис. $1, a)$, а отримана площа фігури $\left(S_{\text {пд}}\right)$ кількісно характеризуватиме якість ПЗ за всіма критеріями одночасно. Площі секторних пелюстків $\left(s_{1}, \ldots, s_{6}\right)$, обмежені полярними секторами $\left(c_{1}, \ldots, c_{6}\right) 3$ кутом $\beta_{j}$ між векторами, будуть кількісно характеризувати якість ПЗ за відповідними критеріями його оцінювання.

Форма пелюсткової діаграми дає якісну характеристику ПЗ за усіма критеріями одночасно, а форма сек-

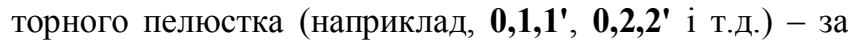
відповідним критерієм. Якщо поділити площу пелюсткової діаграми $\left(S_{\text {пд }}\right)$ на площу круга $\left(S_{\text {кр }}\right)$, в якому вона знаходиться, то отримаємо частку якості ПЗ, яку маємо на даний момент за оцінками певного експерта. Незаповнена площа круга $\left(\Delta S_{\text {кр }}=S_{\text {кр }}-S_{\text {пд }}\right)$ - та частина якості П3, яку ще потрібно досягти для стовідсоткової їі повноти. Якщо поділити площу секторного пелюстка $\left(s_{j}\right)$ на площу сектора $\left(c_{j}\right)$, в якому він знаходиться, то отримаємо частку якості ПЗ за $j$-им критерієм, яку маємо на даний момент за оцінками певного експерта. Незаповнена площа сектора круга $\left(\Delta c_{j}=s_{j}-c_{j}\right)$ - та частина якості ПЗ, яку ще потрібно досягти за відповідним критерієм. Звернемо увагу на те, що радіус круга $(r)$ має відповідати стовідсотковій якості ПЗ за кожним критерієм його оцінювання.

Наведений вище підхід до визначення комплексного показника якості ПЗ та ii (якості) подальшого аналізу є правомірним за певних умов: 1) критеріїв-векторів потрібно не менше трьох; 2) початковий вектор-критерій 00' (рис. 1,б) має знаходитися на додатній осі ординат полярної системи координат, зміщеній проти годинникової стрілки на кут $\beta_{1} / 2$.

Для знаходження площ $\left(s_{1}, \ldots, s_{6}\right)$ секторних пелюстків (див. рис. $1, б)$ через кут $\left(\beta_{j}\right)$ між його радіусами $\left(\rho_{j}\right)$ використаємо таку формулу:

$$
s_{j}=\pi \rho_{j}^{2} \beta_{j}, j=\overline{1, n} .
$$

Відповідно площі секторів круга $\left(c_{1}, \ldots, c_{6}\right)$, складовими яких є секторні пелюстки, через кут $\left(\beta_{j}\right)$ між його радіусами $(r)$ визначають за формулою

$$
c_{j}=\pi r^{2} \beta_{j}, j=\overline{1, n} \text {. }
$$

Отже, формула (2) дає змогу розрахувати площі секторних пелюстків, за допомогою яких обчислюють й оцінюють якість ПЗ за відповідними критеріями. Також ці площі дають змогу визначити ту частину якості ПЗ за певним критерієм, яку маємо на даний момент за оцінками одного 3 експертів, а також ту частку якості П3, яку ще потрібно досягти для стовідсоткової іiї повноти.

Критерії оцінювання якості ПЗ та їхні вагові коефіцієнти. Як було зазначено вище, довжини векторів у полярній системі координат мають відповідати пропорційно значенням відповідних критеріїв оцінювання якості ПЗ, які визначають через оцінки респондентів і ролі кожного 3 них (Botsula \& Morhun, 2008; Mazza, 2009). Зазвичай, респонденти ПЗ є учасниками процесу оцінювання його якості, які можуть виступати в двох ролях - як відповідного експерта, так і безпосереднього користувача. Відмінність ролей у тому, що оцінка якості ПЗ, яку надає певний ексnерт, повинна мати більшу важливість в зазначеному процесі, ніж оцінка, яку надає користувач, позаяк їхня кваліфікація $\epsilon$ різною. Для уникнення подальшої плутанини усіх респондентів будемо називати експертами. Кожному експерту надамо певні вагові коефіцієнти для кожного з критеріїв оцінювання якості ПЗ (табл. 1), значення яких вказуватимуть на їхню обізнаність у певній предметній області (Yakovyna et al., 2010).

Зазвичай, зібрані в інтерактивному режимі оцінки якості ПЗ від кожного з експертів зберігають у базі даних, доступ до якої здійснюють через відповідний програмний засіб (табл. 2 і 3). Отримання оцінок від експертів має проходити у вигляді їхнього опитування з використанням ранжованої шкали за кожним 3 критеріїв (Voronin, Ziatdinov \& Kulinskii, 2011). Експерти мають виставити відповідні оцінки, кожну з яких потім враховують через відповідні вагові коефіцієнти (табл. 1). Зрозуміло, кожен 3 критеріїв буде по різному впливати на комплексний показник якості ПЗ, значення якого згодом визначають для кожного $з$ експертів. Залежно від кваліфікації експерта кожний з них також матиме різні значення коефіцієнтів вагомості (табл. 4).

Введемо множину вагових коефіцієнтів для кожного 3 критеріїв оцінювання якості ПЗ, які надаються кожному $з$ експертів, а саме:

$$
\tilde{\tilde{W}}=\left\{\tilde{W}_{i}=\left\{w_{i, k}=[0(1) 10], k=\overline{1, K}\right\}, i=\overline{1, M}\right\},
$$

де: $w_{i, k}-$ ваговий коефіцієнт $i$-го критерію оцінювання якості ПЗ, який надається $k$-му експерту; $0(1) 10$ - діапазон значень оцінок експертів від 0 до 10 з кроком $1 ; K-$ кількість експертів; $M$ - кількість критеріїв оцінювання якості ПЗ.

У табл. 1 середнє значення вагових коефіцієнтів для $i$-го критерію оцінювання якості ПЗ визначено за такою формулою

$$
\tilde{W}^{\mathrm{c}}=\left\{w_{i}^{\mathrm{c}}=\frac{1}{K} \sum_{k=1}^{K} w_{i, k}, i=\overline{1, M}\right\} .
$$

Для кожного окремого експерта, що бере участь в процедурі оцінювання якості ПЗ, в базі даних має зберігатися сукупність виставлених ним оцінок (див. табл. 2). Також у цій базі даних зберігають ознаки ролей експертів (Botsula \& Morhun, 2008; Paulk \& Curtis, 2001) i коефіцієнти їхньої вагомості (табл. 4). Значення коефіцієнтів вагомості виражають як у абсолютних одиницях, так і у відносних. Ці значення потрібно використати для врегулювання узагальнених показників якості П3, які стосуватимуться окремо статичних (професійних) і динамічних (потенційних користувачів) експертів. Початкові значення коефіцієнтів вагомості експертів, зазвичай, беруть емпірично, виходячи із їхньої важливості на початковому етапі розроблення ПЗ. Насправді ж ці значення потрібно визначати через відповідні тести за 100-бальною шкалою, результати яких вказують реальні значення коефіцієнтів вагомості експертів. 
Табл. 1. Критерії оцінювання якості ПЗ та їхні вагові коефіцієнти

\begin{tabular}{|c|c|c|c|c|c|c|c|}
\hline \multicolumn{8}{|c|}{ Табл. 3. Результати розрахунку комплексних показників якості ПЗ та їжні усереднені значення } \\
\hline \multicolumn{2}{|r|}{ Табл. 4. Обиислення параметрів полярних діаграм (Пелюсткова) } & \multicolumn{3}{|c|}{ Табл. 4. Обчислення параметрів полярних дјаграм (Секторна) } & \multicolumn{2}{|c|}{ Оцінки потенцийних користувачів } & \multirow{2}{*}{$\begin{array}{l}\text { Нки експертіе } \\
\text { мi вагомості }\end{array}$} \\
\hline & 1. Відібрані критеріі та початкові вагові коефіішіенти експе & сним критеріем ошіннвананяя & Табл. 2 & експертів і їپні ваго & & Типи & \\
\hline & Критеріі / Вагові коефішіенти & Eксперт галузі & $\begin{array}{c}\text { Eкcnepт } \\
\text { юзабілі i }\end{array}$ & $\begin{array}{c}\text { Eксперт } 3 \\
\text { програмування }\end{array}$ & $\begin{array}{c}\text { Потенційні } \\
\text { кормстувачі }\end{array}$ & $\Sigma$ & Ср. знач \\
\hline \multirow[t]{11}{*}{ • } & Точність управління та обчислень & 8 & 5 & 9 & 7 & 29 & 7,25 \\
\hline & Ступіньь стандартності інтерфейсів & 7 & 9 & 6 & 5 & 27 & 6.75 \\
\hline & Функціональна повнота & 10 & 6 & 9 & 6 & 31 & 7.75 \\
\hline & Стйкість до помилок & 6 & 4 & 10 & 7 & 27 & 6.75 \\
\hline & Можливість розширення & 5 & 4 & 10 & 4 & 23 & 5.75 \\
\hline & Зручність роботи & 9 & 9 & 7 & 10 & 35 & 8.75 \\
\hline & Простота роботи & 9 & 7 & 6 & 10 & 32 & 8.00 \\
\hline & Відловідність чинним стандартам & 6 & 5 & 10 & 5 & 26 & 6.50 \\
\hline & Переносимість мік ПЗ & 8 & 6 & 9 & 6 & 29 & 7,25 \\
\hline & Зручність навчання & 7 & 8 & 6 & 10 & 31 & 7.75 \\
\hline & & 75 & 63 & 82 & 70 & & 7,25 \\
\hline
\end{tabular}

Табл. 2. Оцінки потенційних користувачів за критеріями оцінювання якості ПЗ

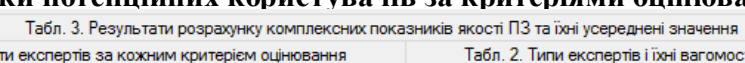

Табл. 1. Відібрані критерї та початкові вагові коефіціенти експертів за кожним критеріем оцінювання

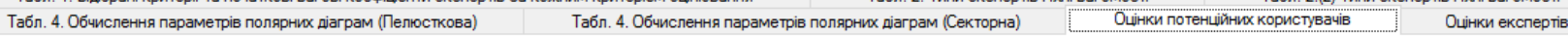

\begin{tabular}{|c|c|c|c|c|c|c|c|c|c|c|c|c|c|c|c|c|c|c|c|c|}
\hline Критеріі & 1 & 2 & 3 & 4 & 5 & 6 & 7 & 8 & 9 & 10 & 11 & 12 & 13 & 14 & 15 & 16 & 17 & 18 & 19 & 20 \\
\hline Точність управління та обиислень & 6 & 8 & 9 & 6 & 9 & 10 & 7 & 7 & 6 & 10 & 10 & 10 & 9 & 6 & 7 & 8 & 6 & 10 & 8 & 9 \\
\hline Ступінь стандартності інтерфейсів & 6 & 8 & 6 & 5 & 8 & 6 & 9 & 7 & 7 & 10 & 10 & 10 & 9 & 10 & 6 & 7 & 5 & 10 & 6 & 5 \\
\hline Функціональна повнота & 6 & 7 & 6 & 4 & 4 & 9 & 8 & 4 & 6 & 9 & 5 & 9 & 8 & 7 & 4 & 4 & 4 & 8 & 4 & 6 \\
\hline Стийкість до помилок & 6 & 8 & 7 & 8 & 8 & 9 & 10 & 10 & 6 & 7 & 7 & 8 & 9 & 8 & 6 & 6 & 6 & 10 & 6 & 9 \\
\hline Можливість розширення & 4 & 5 & 6 & 5 & 5 & 8 & 8 & 9 & 4 & 7 & 4 & 8 & 8 & 7 & 7 & 4 & 4 & 4 & 6 & 8 \\
\hline Зручність роботи & 6 & 6 & 10 & 6 & 7 & 9 & 8 & 10 & 6 & 10 & 10 & 8 & 6 & 9 & 6 & 6 & 8 & 10 & 6 & 10 \\
\hline Простота роботи & 6 & 8 & 9 & 6 & 7 & 7 & 6 & 9 & 6 & 10 & 5 & 10 & 5 & 10 & 8 & 5 & 7 & 8 & 5 & 10 \\
\hline Відловідність чинним стандартам & 6 & 4 & 6 & 4 & 5 & 6 & 8 & 7 & 5 & 6 & 5 & 5 & 4 & 7 & 4 & 4 & 6 & 9 & 6 & 4 \\
\hline Переносимість між ПЗ & 8 & 8 & 10 & 7 & 6 & 7 & 10 & 6 & 6 & 8 & 10 & 6 & 9 & 8 & 9 & 8 & 6 & 9 & 6 & 10 \\
\hline Зручність навчання & 3 & 4 & 6 & 3 & 3 & 3 & 6 & 5 & 5 & 7 & 5 & 5 & 3 & 5 & 3 & 4 & 4 & 3 & 5 & 4 \\
\hline
\end{tabular}

Табл. 3. Зведені оцінки експертів за критеріями оцінювання якості ПЗ

\begin{tabular}{|c|c|c|c|c|c|c|}
\hline \multicolumn{2}{|c|}{ Табл. 1. Вірібрані критерії та початкові вагові коефіціенти експертів за кожним критеріем оцінювання } & \multicolumn{2}{|c|}{ Табл. 2. Типи експертів і їхні вагомості } & \multicolumn{3}{|c|}{ Табл. 2.(2) Типи експертів і їхні вагомості } \\
\hline Табл. 4. Обчислення параметрів полярних дјаграм (Пелюсткова) & \multicolumn{2}{|c|}{ Табл. 4. Обчислення параметрів полярних даграм (Секторна) } & \multicolumn{2}{|c|}{ Оцінки потенцийних користувачів } & \multicolumn{2}{|c|}{ Öніки експертів } \\
\hline Критерії & Експерт галузі & Експерт юзабіліті & $\begin{array}{c}\text { Eксперт } 3 \\
\text { програмування }\end{array}$ & $\begin{array}{l}\text { Потенційні } \\
\text { користувачі }\end{array}$ & Ср. знач & \\
\hline Точність управління та обчислень & 10 & 9 & 10 & 8.05 & 37,05 & \\
\hline Ступінь стандартності інтерфейсів & 9 & 8 & 8 & 7,50 & 32,50 & \\
\hline Функціональна повнота & 9 & 7 & 9 & 6.10 & 31.10 & \\
\hline Стийкість до помилок & 6 & 5 & 8 & 7.70 & 26,70 & \\
\hline Можливість розширення & 7 & 5 & 8 & 6.05 & 26,05 & \\
\hline Зручність роботи & 9 & 7 & 7 & 7.85 & 30,85 & \\
\hline Простота роботи & 10 & 9 & 10 & 7.35 & 36,35 & \\
\hline Відловідність чинним стандартам & 6 & 8 & 7 & 5,55 & 26.55 & \\
\hline Переносимість мік ПЗ & 9 & 7 & 6 & 7,85 & 29,85 & \\
\hline \multirow[t]{2}{*}{ Зручність навчання } & 6 & 5 & 9 & 4,30 & 24,30 & \\
\hline & 8.10 & 7.00 & 8.20 & 6.83 & 30,13 & \\
\hline
\end{tabular}

Табл. 4. Ролі експертів і коефіціснти їхньої вагомості

Табл. 3. Результати розрахунку комплексних показників якості ПЗ та їхні усереднені значення

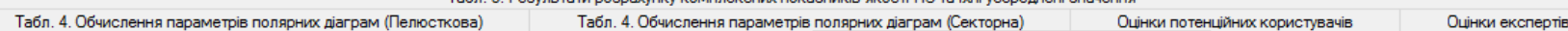

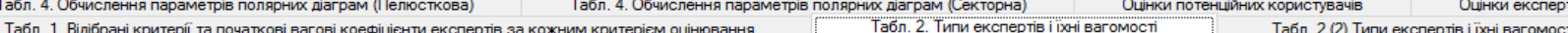

\begin{tabular}{|c|c|c|}
\hline Типи екслертів & Абсопотний коефіціент вагомості. qk & Відносний коефіцјент вагомості, qk \\
\hline Eксперт галузі & 7 & 0.7 \\
\hline Експерт юзабіліті & 8 & 0.8 \\
\hline Експерт з програмування & 9 & 0.9 \\
\hline \multirow[t]{2}{*}{ Потенцийні користувачі } & 5 & 0.5 \\
\hline & 29 & 2,90 \\
\hline
\end{tabular}

Введемо множину коефіцієнтів вагомості, які надамо кожному з експертів під час оцінювання якості ПЗ, а саме:

$$
\tilde{Q}=\left\{q_{k}=[0(0,10) 1], k=\overline{1, K}\right\},
$$

де $q_{k}$ - коефіцієнт вагомості $k$-го експерта під час оцінювання якості ПЗ

Отже, наведено критерії оцінювання якості ПЗ та їхні вагові коефіцієнти для кожного 3 експертів, які мають забезпечити достовірне подання наявного стану процесу розроблення ПЗ, правильне розуміння суті проблем, що можуть виникнути на будь-якому етапі реалізації програмного проекту, і точні характеристики їх складових. Наведено ролі експертів, які мають оцінюва- ти якість ПЗ за відповідними критеріями, і запропоновано орієнтовні коефіцієнти їхньої вагомості.

Визначення комплексних показників якості ПЗ. Для визначення комплексних показників якості ПЗ використаємо сукупність оцінок, які нададуть відповідні експерти - учасники процесу оцінювання його якості (табл. 2 і 3). Постає завдання визначення підсумкових комплексних показників якості ПЗ для кожного 3 експертів зокрема і комплексного узагальненого показника якості ПЗ для усіх експертів загалом (Botsula, \& Morhun, 2014; Morhun, 2011).

Введемо множину оцінок якості ПЗ, які може виставляти будь-який експерт за певним критерієм його оцінювання, а саме 


$$
\tilde{U}=\left\{u_{i}=[1(1) 10], i=\overline{1, M}\right\},
$$

де $u_{i}$ - оцінка якості ПЗ, яку надає експерт за $i$-им критерієм його оцінювання.

Кожна окрема оцінка якості ПЗ за відповідним критерієм, яку надає будь-який експерт, належить цій множині:

$$
\tilde{\tilde{X}}=\left\{\tilde{X}_{i}=\left\{x_{i, k} \in u_{i}, k=\overline{1, K}\right\}, i=\overline{1, M}\right\},
$$

де $x_{i, k}$ - оцінка якості ПЗ за $i$-им критерієм його оцінювання, яку надає $k$-ий експерт у будь-який момент реалізації програмного проекту.

Для кожного експерта введемо таке поняття як комплексний показник якості ПЗ за відповідним критерієм його оцінювання, який можна обчислити за такою формулою:

$$
\tilde{\tilde{G}}=\left\{\tilde{G}_{i}=\left\{g_{i, k}=x_{i, k} \cdot w_{i, k} \cdot q_{k}, k=\overline{1, K}\right\}, i=\overline{1, M}\right\},
$$

де $g_{i, k}-$ комплексний показник якості ПЗ за $i$-им критерієм його оцінювання, який стосується $k$-го експерта. Для узагальненого експерта так званий комплексний показник якості ПЗ за відповідним критерієм його оцінювання обчислимо за такою формулою

$$
\tilde{\tilde{G}}=\left\{\tilde{G}_{i}=\left\{g_{i, K+1}=\sum_{j=1}^{K} x_{i, j} \cdot w_{i, j} \cdot q_{j} / \sum_{j=1}^{K} q_{j}, i=\overline{1, M}\right\},\right.
$$

де $g_{i, K+1}$ - комплексний показник якості П3 за $i$-им критерієм його оцінювання, який стосується узагальненого $(K+1)$-го експерта.

Якщо врахувати, що оцінку якості ПЗ $\left(x_{i, k}\right)$ експерти під час опитування виставляють за 10-бальною шкалою (табл. 2 і 3), ваговий коефіцієнт критерію оцінювання $w_{i, k}$ визначають також за 10-бальною шкалою, а коефіцієнт вагомості експерта $q_{k}$ - безрозмірна величина від 0 до 1 , то комплексний показник якості ПЗ $\left(g_{i, k}\right)$ матиме значення від 0 до 100.

Для обчислення підсумкового комплексного показника якості ПЗ для кожного $з$ експертів використаємо таку формулу

$$
\tilde{D}=\left\{d_{k}=q_{k} \cdot \sum_{i=1}^{M} x_{i, k} \cdot w_{i, k} / \sum_{i=1}^{M} w_{i, k}, k=\overline{1, K}\right\},
$$

а узагальнений комплексний показник якості ПЗ для усіх експертів загалом обчислимо за такою формулою

$$
d^{\mathrm{y}}=\sum_{k=1}^{K} d_{k} / \sum_{k=1}^{K} q_{k} \cdot
$$

В табл. 5 наведено результати розрахунку комплек-

\begin{tabular}{|c|c|c|c|c|c|c|c|c|}
\hline \multicolumn{3}{|c|}{ Табл. 1. Вірібрані критерії та початкові вагові коефішіенти експертів за кожним критеріем оцінюванн } & \multicolumn{3}{|c|}{ Табл. 2. Типи експертів і їжні вагомості } & \multicolumn{3}{|c|}{ Табл. 2.(2) Типи експертів і ї̈ні вагомості } \\
\hline \multirow{2}{*}{\multicolumn{2}{|c|}{$\begin{array}{l}\text { Табл. 4. Обиислення параметрів полярних діаграм (Пелюсткова) } \\
\text { Табл. }\end{array}$}} & \multicolumn{3}{|c|}{ Табл. 4. Обчислення параметрів полярних даграм (Секторна) } & \multirow{2}{*}{\multicolumn{2}{|c|}{$\begin{array}{l}\text { Оцінки потенційних користувачів } \\
\text { i значення }\end{array}$}} & \multicolumn{2}{|c|}{ Оцінки експертів } \\
\hline & & ати розрахунку компле & знників 9к & 73 та їніi усереднен & & & & \\
\hline \multirow{2}{*}{ № $3 / n$} & \multirow{2}{*}{ Қритерії ошінювання якості ПЗ } & \multicolumn{3}{|c|}{ Ощннки експертів (фi.k) } & \multirow{2}{*}{$\begin{array}{c}\text { Оцинкии } \\
\text { користувачів (xi.K) }\end{array}$} & \multicolumn{2}{|c|}{ Усереднені оцннки } & \\
\hline & & галузі & юзабіiniтi & з програмування & & $\left.\sum w_{i j} \times j\right]^{*} q k / \sum q(k)$ & $\mathrm{x}$ & \\
\hline & Коефіценнти вагомості. qk & 0.70 & 0.80 & 0.90 & 0.50 & 0.725 & & \\
\hline 1 & Точність управління та обчислень & 80 & 45 & 90 & 56,35 & 69.37 & 9.57 & 69.37 \\
\hline 2 & Ступінь стандартності інтерфейсів & 63 & 72 & 48 & 37,50 & 56,43 & 8.36 & 56.43 \\
\hline 3 & Функціональна повнота & 90 & 42 & 81 & 36,60 & 64.76 & 8.36 & 64,76 \\
\hline 4 & Стийкість до помилок & 36 & 20 & 80 & 53.90 & 48,33 & 7.16 & 48,33 \\
\hline 5 & Можливість розширення & 35 & 20 & 80 & 24,20 & 42,97 & 7,47 & 42,97 \\
\hline 6 & Зручність роботи & 81 & 63 & 49 & 78,50 & 65.67 & 7.51 & 65.67 \\
\hline 7 & Простота роботи & 90 & 63 & 60 & 73,50 & 70,40 & 8.80 & 70,40 \\
\hline 8 & Відловідність чинним стандартам & 36 & 40 & 70 & 27.75 & 46,23 & 7.11 & 46.23 \\
\hline 9 & Переносимість між П3 & 72 & 42 & 54 & 47.10 & 53,84 & 7.43 & 53.84 \\
\hline \multirow[t]{3}{*}{10} & Зручність навчання & 42 & 40 & 54 & 43,00 & 45,34 & 5.85 & 45,34 \\
\hline & Усереднені оцінки & 8.33 & 7.10 & 8.12 & 6.83 & 7.77 & 7.76 & \\
\hline & Оцінки з врахуванням вагомості експертів & 5,83 & 5,68 & 7.31 & 3.42 & 7.60 & 7.67 & \\
\hline
\end{tabular}
сних показників якості ПЗ та їхні усереднені значення з врахуванням вагових коефіцієнтів критеріїв його оцінювання, а також вагомості кожного з експертів зокрема і усіх експертів загалом.

Табл. 5. Результати розрахунку комплексних показників якості ПЗ та їхні усереднені значення

Алгоритм розрахунку площі пелюсткової діаграми. Комплексні показники якості ПЗ подамо у вигляді векторів полярної системи координат, які мають утворити пелюсткові діаграми для кожного експерта зокрема і узагальненого експерта загалом. Кожний такий вектор характеризується відповідно довжиною і кутом до попереднього вектора. Як було зазначено вище, довжина вектора у будь-якому випадку має відповідати кількісному значенню комплексного показника якості ПЗ за відповідним критерієм.

Звернемо увагу на те, що площа пелюсткової діаграми кількісно характеризує якість ПЗ за всіма критеріями одночасно, а форма діаграми дає якісну характеристику ПЗ. Для знаходження координат вершин пелюсткової діаграми 1-1',2-2',...,6-6' (див. рис. 1,a) використаємо такий алгоритм розрахунку.

У випадку неоднакового впливу критеріїв на якість П3 (див. формулу (1)) кути між відповідними векторами з врахуванням (4) визначають за такою формулою

$$
\tilde{\mathrm{B}}_{k}=\left\{\beta_{i, k}=2 \pi \cdot w_{i, k} / \sum_{j=1}^{M} w_{j, k}, i=\overline{1, M}\right\}, k=\overline{1, K},
$$

а для середнього значення оцінок якості ПЗ (тобто, $k=$ $K+1)$ з врахуванням (5) ця формула матиме вигляд

$$
\tilde{\mathrm{B}}_{k}=\left\{\beta_{i, k}=2 \pi \cdot w_{i}^{\mathrm{c}} / \sum_{j=1}^{M} w_{j}^{\mathrm{c}}, i=\overline{1, M}\right\}, k=K+1 .
$$

Оскільки полярний сектор з кутом $\beta_{j}$ потрібно починати $з$ вектора-критерію (див. формулу (1)), то перший вектор-критерій має знаходитися на осі ординат у полярній системі координат, але зміщеному проти годинникової стрілки на кут $\beta_{1} / 2$. Тому початок відліку кута $\beta_{1, k}(\forall k \in K+1)$, який відповідає 1-му полярному сектору, почнемо зі значення кута $\alpha_{1, k}=-\beta_{1, k} / 2(\forall k \in K+1)$, а всі інші кути обчислимо за такою формулою

$$
\tilde{\mathrm{A}}_{k}=\left\{\alpha_{1, k}=-\beta_{1, k} / 2 ; \alpha_{i, k}=\alpha_{i-1, k}+\beta_{i, k}, i=\overline{2, M}\right\}, k \in K+1 .
$$

Для побудови пелюсткової діаграми потрібно 3 кінців кожного вектора провести дуги на відповідний кут $\alpha_{i, k}(\forall i \in M, \forall k \in K+1)$. Маючи значення довжин векторів-критеріїв, отримані за формулою (9) чи (10), а також кути між ними, отримані за формулою (15), можна побудувати пелюсткові діаграми для будь-якого з експертів зокрема, в т.ч. і для узагальненого $(K+1)$-го експерта загалом (рис. 2). 
Табп. 1. Вірібрані критерї та початкові вагові коефіцентти експертів за кожним критеріем оцінювання

Табл. 2. Типи експертів і їx-1 вагомост Табл. 3. Результати розрахунку комплексних показників якості ПЗ та їхі усереднені значення

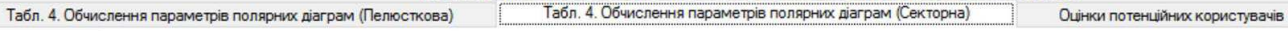
Oürки експертів Eксперти галузі Експерти юзабіліті Експерт з програмування Потенсійні користувачі Усереднені значення Узагальнені дані

\begin{tabular}{|c|c|c|c|c|c|}
\hline & Критерії / Вагові коефіціенти & Ekcnept & $\mathrm{Si}$ & G & $\Delta \mathrm{G}$ \\
\hline 1 & Точність управління та обиислень & 8 & 1050.88 & 3351,03 & 2300.15 \\
\hline 2 & Ступінь стандартності інтерфейсів & 7 & 570.25 & 2932,15 & 2361,90 \\
\hline 3 & Функцональна повнота & 10 & 1662.53 & 4188,79 & 2526.26 \\
\hline 4 & Стйкість до помилок & 6 & 159.60 & 2513.27 & 2353.67 \\
\hline 5 & Можливість розширення & 5 & 125,72 & 2094,40 & 1968.68 \\
\hline 6 & Зручність роботи & 9 & 1211.98 & 3769.91 & 2557.93 \\
\hline 7 & Простота роботи & 9 & 1496.28 & 3769.91 & 2273.63 \\
\hline 8 & Відловідність чинним стандартам & 6 & 159.60 & 2513.27 & 2353.67 \\
\hline 9 & Переносимість мік ПЗ & 8 & 851.22 & 3351,03 & 2499,81 \\
\hline \multirow[t]{2}{*}{10} & Зручність навчання & 7 & 253.44 & 2932,15 & 2678.71 \\
\hline & & 75 & 7541.50 & 31415.93 & 23874,43 \\
\hline
\end{tabular}

Результати оцінювання якості ПЗ експертом галузі:

$\mathrm{S} 1=7541,50$ ум. 0 . $z 1=0,2401$

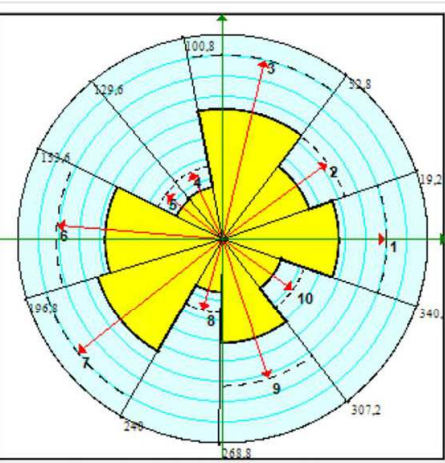

Експерти галузі Eксперти юзабіліті] Експерт з програмування Потенсійні користуваиі Усереднені значення Узагальнені дані

\begin{tabular}{|c|c|c|c|c|c|}
\hline & Критеріі / Вагові коефіціенти & $\begin{array}{c}\text { Ekcnepr } \\
\text { юзабабілі }\end{array}$ & Si & G & $\Delta \mathrm{G}$ \\
\hline b 1 & Точність управління та обчиспень & 5 & 323.12 & 2493.20 & 2170,08 \\
\hline 2 & Ступінь стандартності інтерфейсів & 9 & 1489,05 & 4488.11 & 2999.06 \\
\hline 3 & Функцінапьна повнота & 6 & 337.83 & 2992,37 & 2654,54 \\
\hline 4 & Стйкість до помилок & 4 & 51.07 & 1994.91 & 1943,84 \\
\hline 5 & Можливість розширення & 4 & 51.07 & 1994.91 & 1943,84 \\
\hline 6 & Зручність роботи & 9 & 1140,05 & 4488,11 & 3348,06 \\
\hline 7 & Простота роботи & 7 & 886,68 & 3490,66 & 2603,98 \\
\hline 8 & Відловідність чинним стандартам & 5 & 255.30 & 2493.20 & 2237.90 \\
\hline 9 & Переносимість мік ПЗ & 6 & 337,83 & 2992.37 & 2654.54 \\
\hline \multirow[t]{2}{*}{10} & Зручність навчання & 8 & 408,47 & 3988.95 & 3580,48 \\
\hline & & 63 & 5280,47 & 31416,80 & 26136,33 \\
\hline
\end{tabular}

Результати оцінювання якості ПЗ експертом юзабіліті:

$\mathrm{S} 2=5280,47 \mathrm{ym} .0$. $z 2=0,1681$

Eксnерти галузі Eксперти юзабіліт [Експерт з програмування] Потенсійні користувачі Усереднені значення Узагальнені дані

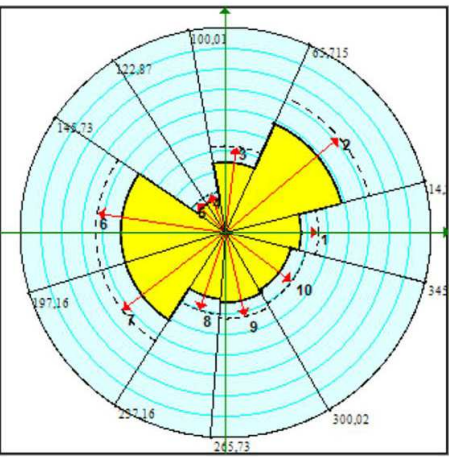

\begin{tabular}{|c|c|c|c|c|c|}
\hline & Критерії / Вагові коефіціенти & $\begin{array}{c}\text { Eкслерт } \mathbf{s} \\
\text { пограмуванн }\end{array}$ & Si & a & $\Delta G$ \\
\hline 1 & Точність управління та обчислень & 9 & 2262,17 & 3447,90 & 1185,73 \\
\hline 2 & Ступінь стандартності інтерфейсів & 6 & 428.97 & 2298,60 & 1869.63 \\
\hline 3 & Функцональна повнота & 9 & 1832.36 & 3447,90 & 1615,54 \\
\hline 4 & Стийкість до помилок & 10 & 1985.99 & 3831,00 & 1845.01 \\
\hline 5 & Можливість розширення & 10 & 1985,99 & 3831,00 & 1845,01 \\
\hline 6 & Зручність роботи & 7 & 521,54 & 2681.70 & 2160.16 \\
\hline 7 & Простота роботи & 6 & 670.27 & 2298.60 & 1628,33 \\
\hline 8 & Відловідність чинним стандартам & 10 & 1520,52 & 3831,00 & 2310,48 \\
\hline 9 & Переносимість міх ПЗ & 9 & 814,38 & 3447,90 & 2633,52 \\
\hline \multirow[t]{2}{*}{10} & Зручність навчання & 6 & 542,92 & 2298,60 & 1755,68 \\
\hline & & 82 & 12565.11 & 31414.18 & 18849.07 \\
\hline
\end{tabular}

Результати оцінювання якості ПЗ експертом з програмування:

S3= 12565,11 ум. $\circ$. $z 3=0.4000$

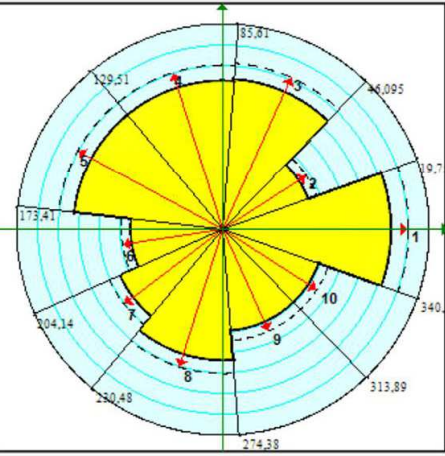

Eксперти гапузі Eксперти юзабіліті Експерт з програмування Потенсійні користувачі] Усерепнені значення Узагальнені дані

\begin{tabular}{|c|c|c|c|c|c|}
\hline & Критеріі / Вагові коефіціенти & $\begin{array}{c}\text { Потенційні } \\
\text { користувачі }\end{array}$ & $\mathrm{Si}$ & $G$ & $\Delta G$ \\
\hline - 1 & Touнicts yправління та обчислень & 7 & 249.39 & 3141.59 & 2892,20 \\
\hline 2 & Ступінь стандартності інтерфейсів & 5 & 78.88 & 2243.62 & 2164,74 \\
\hline 3 & Функціональна повнота & 6 & 90.19 & 2693,04 & 2602,85 \\
\hline 4 & Стйкість до помилок & 7 & 228.17 & 3141,59 & 2913.42 \\
\hline 5 & Мохливість розширення & 4 & 26,28 & 1795.07 & 1768.79 \\
\hline 6 & Зручність роботи & 10 & 691,42 & 4488.11 & 3796.69 \\
\hline 7 & Простота роботи & 10 & 606.15 & 4488.11 & 3881,96 \\
\hline 8 & Вілловідність чинним стандартам & 5 & 43,19 & 2243,62 & 2200,43 \\
\hline 9 & Переносимість мік ПЗ & 6 & 149,36 & 2693,04 & 2543,68 \\
\hline \multirow[t]{2}{*}{10} & Зручність навчання & 10 & 207.46 & 4488.11 & 4280.65 \\
\hline & & 70 & 2370,49 & 31415.93 & 29045.44 \\
\hline & дійним & тув & $\begin{array}{l}\mathrm{S} 4= \\
\mathrm{z} 4=\end{array}$ & 19 ум. \\
\hline
\end{tabular}

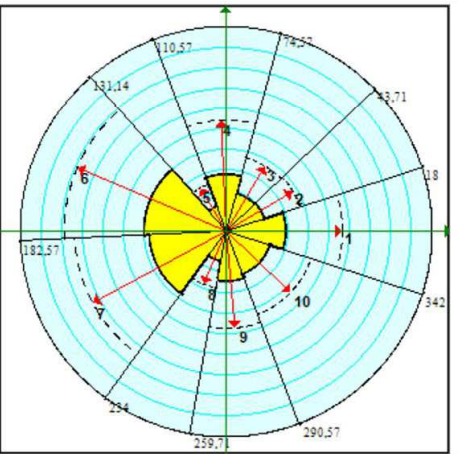

Eксперти галузі Експерти юзабіліті Експерт з програмування Потенсійні користувачі [Усереднені значення] Узагальнені дані

\begin{tabular}{|c|c|c|c|c|c|}
\hline & Критерії / Вагові коефішіенти & $\begin{array}{c}\text { Уsaranьнені } \\
\text { значення }\end{array}$ & $\mathrm{Si}$ & G & $\Delta \mathrm{G}$ \\
\hline 1 & Точність управління та обчислень & 7.25 & 1511.83 & 3141.59 & 1629.76 \\
\hline 2 & Ступінь стандартності інтерфейсів & 6.75 & 931,51 & 2925.17 & 1993,66 \\
\hline 3 & Функцональна повнота & 7.75 & 1408.24 & 3358.01 & 1949.77 \\
\hline 4 & Стйикість до помилок & 6.75 & 683.19 & 2925,17 & 2241.98 \\
\hline 5 & Можливість розширення & 5.75 & 459.93 & 2491.46 & 2031.53 \\
\hline 6 & Зручність роботи & 8.75 & 1635,32 & 3791,73 & 2156,41 \\
\hline 7 & Простота роботи & 8.00 & 1717.75 & 3466.22 & 1748.47 \\
\hline 8 & Відловідність чинним стандартам & 6.50 & 602,12 & 2816.96 & 2214,84 \\
\hline 9 & Переносимість мік ПЗ & 7.25 & 910.83 & 3141.59 & 2230.76 \\
\hline \multirow[t]{2}{*}{10} & Зручність навчання & 7.75 & 690,46 & 3358,01 & 2667.55 \\
\hline & & 72,50 & 10551.17 & 31415.93 & 20864.76 \\
\hline
\end{tabular}

Результати оцінювання якості ПЗ за узагальненими показниками: $S=10551,17$ ум. o. $z=0,3359$

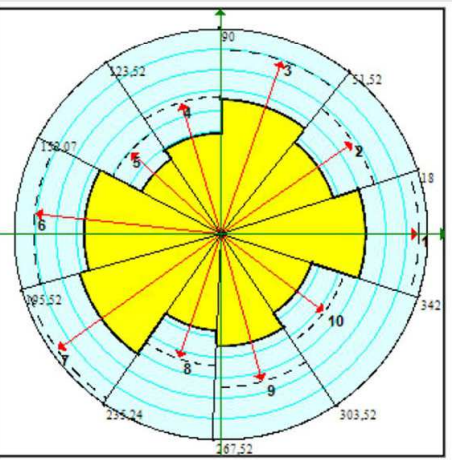

Рис. 2. Подання результатів оцінювання якості ПЗ у вигляді пелюсткових діаграм для відповідних експертів 
Табл. 6. Результати розрахунку узагальнених комплексних показників якості ПЗ

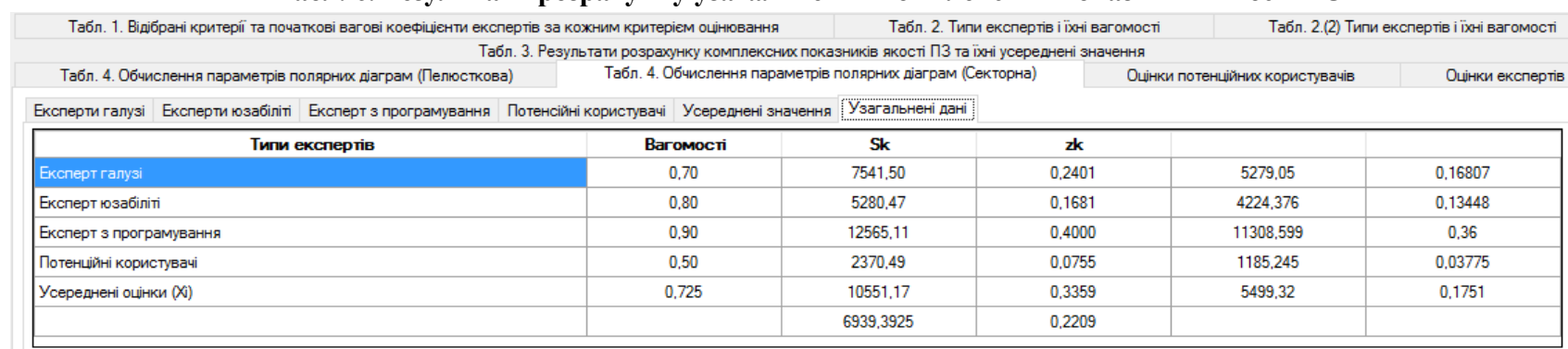

Як було зазначено вище, форма пелюсткової діаграми, побудованої за вершинами векторів-критеріїв, для будь-якого експерта дає якісну характеристику ПЗ за вибраними критеріями його оцінювання. Водночас, отримана площа пелюстка буде кількісно характеризувати якість ПЗ одночасно за всіма критеріями.

Для знаходження площі пелюсткової діаграми за координатами вершин iii векторів-критеріїв можна використати таку формулу

$$
S_{k}^{\text {пג }}=\pi \sum_{i=1}^{M} g_{i, k}^{2} \cdot \beta_{i, k}, k \in K+1 .
$$

Для встановлення частки наявної якості ПЗ, яку маємо на даний момент за оцінками певного експерта, потрібно поділити площу пелюсткової діаграми на площу круга, в якому вона знаходиться, а саме

$$
z_{k}=\frac{S_{k}^{\text {пा }}}{\pi r^{2}}, k \in K+1,
$$

де: $z_{k}$ - частка наявної якості ПЗ, яку встановлено за даними $k$-го експерта; $r$ - радіус круга. Як було зазначено вище, комплексний показник якості ПЗ $\left(g_{i, k}\right)$ матиме максимальне значення 100 , тобто радіус круга становитиме 100 од. Незаповнена ж площа круга - та частка якості ПЗ, яку ще потрібно досягнути для стовідсоткової iï повноти.

3 наведеного вище матеріалу видно, що у цій роботі розроблено методику візуалізації результатів експертного оцінювання якості ПЗ, яка полягає у тому, що результатом оцінювання $є$ множина пелюсткових діаграм, побудованих у полярній системі координат за оцінками окремих експертів 3 врахуванням важливості кожного 3 критеріїв оцінювання і вагомостей самих експертів. Такий механізм візуалізації інформації надає можливість бізнес-аналітикам якісно та кількісно подати множини значень комплексних показників якості ПЗ, які можна отримати за результатами будь-якого опитування різних експертів на певному етапі реалізації програмного проекту (Hrytsiuk \& Nemova, 2018a, 2018b). Запропонована методика $€$ повністю придатною для подання множини результатів опитувань експертів 3 поділом на необмежену кількість ролей учасників оцінювання якості ПЗ з врахуванням вагомості кожного з них.

Отже, розроблено методику розрахунку підсумкових комплексних показників якості ПЗ для кожного 3 експертів зокрема i узагальнений комплексний показник його якості для усіх експертів загалом, які дають змогу бізнес-аналітикам обчислити і оцінити якість розроблюваного ПЗ на будь-якому етапі реалізації програмного проекту як статично, так і в динаміці.

Також розроблено алгоритм розрахунку площі пелюсткової діаграми, побудованого у полярній системі координат за результатами експертного оцінювання якості ПЗ. Знання площі пелюсткової діаграми дає можливість аналітикам кількісно оцінити якість ПЗ за всіма критеріями, а форма діаграми дає якісну характеристику ПЗ. Ця площа дає змогу визначити ту частину якості ПЗ за всіма критеріями одночасно, яку маємо на даний момент за оцінками одного з експертів, а також ту частку якості ПЗ, яку ще потрібно досягти для стовідсоткової її повноти.

Висновки. Розроблено методику візуалізації інформації, отриману внаслідок оброблення експертних оцінок якості ПЗ за різними критеріями його оцінювання 3 використанням пелюсткових діаграм. За результатами дослідження можна зробити такі основні висновки.

1. Обгрунтовано подання оцінок експертів у вигляді полярних діаграм, які дають змогу лаконічно навести в зображенні те, що в текстовому еквіваленті займе декілька абзаців. Розроблено алгоритм розрахунку площ секторних пелюстків у полярній системі координат, за допомогою яких можна обчислити і оцінити відносну якість ПЗ за відповідними критеріями його оцінювання.

2. Запропоновано критерії оцінювання якості ПЗ та їхні вагові коефіцієнти для кожного з експертів, які забезпечують достовірне подання наявного стану процесу розроблення ПЗ, правильне розуміння суті проблем, що можуть виникнути на будь-якому етапі реалізації програмного проекту, і точні характеристики їх складових.

3. Визначено підсумкові комплексні показники якості ПЗ для кожного з експертів зокрема і узагальнений комплексний показник його якості для усіх експертів загалом. Розроблено алгоритм розрахунку площі пелюсткової діаграми у полярній системі координат, яка дає змогу визначити ту частину якості ПЗ за всіма критеріями, що маємо на даний момент за оцінками одного з експертів, а також ту частку якості ПЗ, яку ще потрібно досягти для стовідсоткової її повноти.

4. Зроблено відповідні висновки та надано рекомендації щодо використання розробленої методики візуалізації інформації.

\section{Перелік використаних джерел}

Bederson, B., \& Shneiderman, B. (2003). The Craft of Information Visualization: Readings and Reflections. Morgan Kaufmann. 410 p.

Botsula, M. P., \& Morhun, I. A. (2008). Pro problemu ekspertyzy yakosti materialiv dystantsiinykh kursiv. Naukovi pratsi VNTU, 4, 17. Retrieved from: http://nbuv.gov.ua/e-iournals/vntu/2008-4/20084.files/uk/08mpbcme uk.pdf. [In Ukrainian].

Botsula, M. P., \& Morhun, I. A. (2011). Metod otrymannia kompleksnoi otsinky yakosti veb-materialiv z vykorystanniam poliarnoi systemy koordynat. Visnyk Vinnytskoho politekhnichnoho instytutu, 1, 84-88. Retrieved from: https://visnyk.vntu.edu.ua/index.php/visnyk/article/view/1367/conferences.vntu.edu.ua. [In Ukrainian].

Botsula, M. P., \& Morhun, I. A. (2014). Novyi metod ta informatsiina tekhnolohiia obroblennia danykh dlia upravlinnia yakistiu elektronnykh navchalnykh kursiv. Informatsiini tekhnolohii ta kompiuterna inzheneriia: mizhnarodnyi naukovo-tekhnichnyi zhurnal, 3, 25-33. Retrieved from: http://nbuv.gov.ua/UJRN/Itki_2014_3_6. [In Ukrainian]. 
Card, S. K., Mackinlay, J. D., \& Shneiderman, B. (1999). Readings in Information Visualization: Using Vision to Think. Morgan Kaufmann Publishers. 686 p.

DeMarco Tom. (2002). Controlling Software Projects: Management, Measurement and Estimation. 279 p.

Heer, J., Card, S. K., \& Landay, J. (2005). Prefuse: a toolkit for interactive information visualization, $(10$ p.). In: ACM Human Factors in Computing Systems CHI 2005. 280 p.

Hrytsiuk, Yu. I. (2018). Analysis of Software Requirements: Tutorial. Lviv: Publishing House of Lviv Polytechnic. 460 p. https://192.168.253.4/Research/TrainingAidsEdit.aspx?id=11750. [In Ukrainian].

Hrytsiuk, Yu. I., \& Buchkovska, A. Yu. (2017a). Visualization of the Results of Expert Evaluation of Software Quality Using Polar Diagrams. Scientific Bulletin of UNFU, 27(4), 137-145. https://doi.org/10.15421/40271025

Hrytsiuk, Yu. I., \& Buchkovska, A. Yu. (2017b). Visualization of expert evaluation of software quality using polar diagrams. Problems of the use of information technologies by law enforcement structures of Ukraine and higher educational institutions with specific learning conditions: a collection of scientific articles based on the reports of the participants of the International Scientific and Practical Conference, (pp. 160-167), December 22, Lviv, Ukraine. Lviv: Publishing House of Lviv State University of Internal Affairs. Retrieved from: http://www.lvduvs.edu.ua/documents pdf/bibliote$\mathrm{ka} /$ nauk konf/22 12 2017.pdf

Hrytsiuk, Yu. I., \& Nemova, E. A. (2018a). Peculiarities of Formulation of Requirements to the Software. Scientific Bulletin of UNFU, 28(7), 135-148. https://doi.org/10.15421/40280727

Hrytsiuk, Yu. I., \& Zhabych, M. R. (2018). Risk Management of Implementation of Program Projects. Scientific Bulletin of UNFU, 28(1), 150-162. https://doi.org/10.15421/40280130

Hrytsiuk, Yu. I., \& Nemova, E. A. (2018b). Management Features Process of Developing Software Requirements. Scientific Bulletin of UNFU, 28(8), 161-169. https://doi.org/10.15421/40280832

ISO 9001:2008. Quality Management System - requirements. Retrieved from: https://www.iso.org/standard/46486.html

ISO/IEC 9126. (1991). Information technology - Software product evaluation - Quality characteristics and guidelines for their use. Geneva: International Organization for Standardization, International Electrotechnical Commission, 136 p. (International Standard)

ISO/IEC 9126-1:2001. Software Engineering - Product Quality. Part 1: Quality model. Retrieved from: https://www.iso.org/standard/22749.html

ISO/IEC TR 9126-2:2003. Software Engineering - Product Quality Part 2: External metrics. Retrieved from: https://www.iso.org/standard/22750.html

ISO/IEC TR 9126-3:2003. Software Engineering - Product Quality Part 3: Internal metrics. Retrieved from: https://www.iso.org/standard/22891.html
ISO/IEC TR 9126-4:2004. Software Engineering - Product Quality Part 4: Quality in use metric. Retrieved from: https://www.iso.org/standard/39752.html

Kerren, A., Stasko, J. T., Fekete, J.-D., \& North, C. (Eds.) (2008). Information Visualization, (pp. 1-18). In: Human-Centered Issues and Perspectives. Vol. 4950 of LNCS State-of-the-Art Survey. Springer-Verlag Berlin Heidelberg 2008.

Kuliamin, V. V., Petrenko, O. L. (2008). Mesto testirovaniia sredi metodov otcenki kachestva PO. Moscow: ISP RAN. Retrieved from: http://software-testing.ru/library/5-testing/117-2008-10-13-19-2513. [In Russian].

Mazza, R. (2009). Introduction to Information Visualization, University of Lugano Switzerland. Springer-Verlag London Limited 2009. 139 p. https://doi.org/10.1007/978-1-84800-219-7

Morhun, I. A. (2011). Metod ekspertnoi otsinky yakosti prohramnoho zabezpechennia. Inzheneriia prohramnoho zabezpechennia: mater. Mizhnar. nauk.-prakt. konf. aspirantiv i studentiv, 2(6), 33-37. Vinnytsia. Retrieved from: http://jrnl.nau.edu.ua/index.php/IPZ/article/view/3086. [In Ukrainian].

Nazemi, K. (2014). Adaptive Semantics Visualization. Dissertation zur Erlangung des akademischen Grades eines Doktor-Ingenieurs. Eurographics Association for Computer Graphics. 360 p. Retrieved from: http://diglib.eg.org/handle/10.2312/12076

Paulk, M. C., \& Curtis, B. (2001). The Capability Maturity Model: Guideline for Improving the Software Process. Carnegie Mellon University. $434 \mathrm{p}$.

Pleskach, V. L., Zatonatska, T. H. (2011). Informatsiini systemy y tekhnolohii na pidpryiemstvakh: pidruchnyk. Kyiv: Znannia. 718 p. Retrieved from: http://pidruchniki.com/1194121347734/informatika/analiz yakosti programnogo zabezpechennya\#42. [In Ukrainian].

Pomorova, O. V., \& Hovorushchenko, T. O. (2013a). Suchasni problemy otsiniuvannia yakosti prohramnoho zabezpechennia. Radioelektronni i kompiuterni systemy, 5, 319-327. Kharkiv: NAU "KhAI". [In Ukrainian].

Pomorova, O., \& Hovorushchenko, T. (2013b). Intelligent Assessment and Prediction of Software Characteristics at the Design Stage. American Journal of Software Engineering and Applications (AJSEA), 2(2), 25-31. Retrieved from: http://article.sciencepublishinggroup.com/pdf/10.11648.j.ajsea.20130202.11.pdf.

Spence, R. (2007). Information Visualization: Design for Interaction (2nd Ed.). Prentice Hall. 304 p.

Voronin, A. N., Ziatdinov, Yu. K., \& Kulinskii, M. V. (2011). Mnogokriterialnye zadachi: modeli i metody: monografiia. Kiev: NAU. 348 p. [In Russian].

Ware, C. (2000). Information Visualization: Perception for design (2nd Ed.). San Francisco, CA: Morgan Kaufmann Publishers. 34 p.

Yakovyna, V., Seniv, M., Chabaniuk, Ya., Fedasiuk, D., \& Khimka, U. (2010). Kryterii dostatnosti protsesu testuvannia prohramnoho zabezpechennia. Visnyk Natsionalnoho universytetu "Lvivska politekhnika". Seriia: Kompiuterni nauky ta informatsiini tekhnolohii, 672, 346-358. [In Ukrainian].

Ю. И. Грыцюк, В. С. Далявский

Национальный университет "Львовская политехника", г. Львов, Украина

\section{ИСПОЛЬЗОВАНИЕ ЛЕПЕСТКОВОЙ ДИАГРАММЫ ДЛЯ ВИЗУАЛИЗАЦИИ РЕЗУЛЬТАТОВ ЭКСПЕРТНОЙ ОЦЕНКИ КАЧЕСТВА ПРОГРАММНОГО ОБЕСПЕЧЕНИЯ}

Разработана методика визуализации информации, которую можно получить в результате обработки экспертных оценок качества программного обеспечения (ПО) по различным критериям с использованием лепестковых диаграмм. Установлено, что под визуализацией результатов экспертного оценивания качества ПО понимают представление информации в графическом виде для максимального удобства ее понимания и быстрого восприятия, а также предоставление обозримой и понятной формы любому объекту, процессу или явлению. Предложены критерии оценки качества ПО и их весовые коэффициенты для каждого из экспертов, обеспечивающие достоверное представление существующего положения процесса разработки ПО, правильное понимание сути проблем, возникающих на любом этапе реализации программного проекта, и точные характеристики их составляющих. Разработан алгоритм расчета площадей секторных лепестков в полярной системе координат, с помощью которого можно вычислить и оценить относительное качество ПО с применением соответствующих критериев. Определены итоговые комплексные показатели качества ПО для каждого из экспертов и обобщенный комплексный показатель его качества для всех экспертов. Разработан алгоритм расчета площади лепестковой диаграммы в полярной системе координат, позволяющий определить ту часть качества программного продукта по всем критериям, имеющуюся на данный момент по оценкам одного из экспертов, а также ту часть качества ПО, которое еще нужно достичь для стопроцен- 
тной его полноты. Сделаны соответствующие выводы и даны рекомендации по использованию разработанной методологии визуализации информации.

Ключевые слова: информационные технологии; программный проект; визуализация информации; экспертные оценки; качество программного обеспечения; критерии оценки качества; показатели качества; полярная система координат; полярные диаграммы.

Yu. I. Hrytsiuk, V. S. Dalyavskyy

Lviv Polytechnic National University, Lviv, Ukraine

\section{USING PETAL DIAGRAM FOR VISUALIZING THE RESULTS OF EXPERT EVALUATION}

OF SOFTWARE QUALITY

The technique of imaging information obtained by processing the expert software quality estimates according to various criteria using petal diagrams. It was found that under the visualization of the results of the expert evaluation of quality software realize the provision of information in graphical form for the maximum comfort of its understanding and quick perception, as well as providing foreseeable and understandable form any object, process or phenomenon. Criteria of evaluation of the quality of the software and their weights for each of the experts, to ensure fair presentation of the current status of the software development process, the proper understanding of the problems that arise at any stage of a software project, and the exact characteristics of their constituents. Such information rendering engine allows analysts to qualitatively and quantitatively provide the customer with a set of values of complex parameters of quality software that you can get the results of any survey of various experts in a particular phase of the software project. The proposed method is suitable for the representation of the set of results expert surveys division them on an unlimited number of roles, quality evaluation participants by taking into account the weight of each of them. An algorithm for calculating the space sector petals in the polar coordinate system, with which you can calculate and assess the relative quality of software to meet the relevant criteria. Identified the integrated quality score for each of the experts and the generalized complex index of quality assurance for all experts. An algorithm for calculating the area of petal diagram in the polar coordinate system. The algorithm allows to determine the quality of the software product on all the criteria available at this time estimated by an expert, as well as the quality of the software that has to be achieved to its absolute completeness. Appropriate conclusions and recommendations on the use of information visualization methodologies developed.

Keywords: information technologies; software project; information visualization; expert assessments; software quality; criteria for quality evaluation; software quality indicators; polar coordinate system; polar diagrams. 